\title{
Recuperating Democratic Spaces in an Age of Militarisation and a 'New Fascism'
}

\author{
PETER MAYO \\ Department of Education Studies, \\ University of Malta
}

\begin{abstract}
This essay provides a comprehensive overview of Henry Giroux's contribution over the years to critical thinking in education and beyond. It focuses primarily on Giroux's recent works concerning the changing nature of the State (from the social to the carceral and neoliberal state), the war against youth and children, the culture of militarisation, torture, the emergence of a 'new fascism', the corporatisation of schools and higher education and the need for intellectuals to extend their work beyond the confines of academia to engage as public intellectuals, as well as the roles of critical pedagogy and cultural studies in this regard. The article draws on a range of writings, including both academic and more 'public' writings from such outlets as Truthout and Counterpunch. While much of what is written presents a bleak picture of the current international socio-economic scenario, Giroux's work is infused with a sense of hope and agency. It is inspired by a view of a world not as it is now but as it can and should be.
\end{abstract}

\section{Introduction}

In my almost quarter century of immersion in critical pedagogy, a number of figures have turned out to be most influential. Foremost would be Gramsci, Freire and more recently Lorenzo Milani. Henry Giroux, whom I have come to value as a personal friend, certainly figures prominently in this regard (Giroux, 2011b) as his work remains a constant source of reference. He is, after all, one of the founding figures of the critical pedagogy movement. And his writings are not confined to just education, whichever way this area is viewed, but span a variety of topics that render him, in my estimation and that of many others, one of North America's leading public intellectuals.

\section{Prolific Writer}

Catching up with Giroux's output is quite a tall order given that he is so prolific in terms of writing books, articles which appear in countless top-notch peer-reviewed journals, interviews appearing in various media and articles in the press (electronic reviews or mass-circulated newspapers). It all started in 1986 when I was a graduate student taking Professor Raymond A. Morrow's class in the 'History of Sociological Thought' at the University of Alberta (Edmonton, Canada), and the course professor forwarded me his personal copy of Theory and Resistance. I was encouraged to consult this work to gain some insight into the debates around Marxism and education in view of the course paper I was due to write (this was my first semester of graduate studies). Having followed Giroux's writing and talks (through videos and podcasts) over the years, I could keep track of the changes that marked different periods in his evolution as a thinker and writer. This also included changes in his style of writing. The passion for which he is noted always continued to be there and, if anything, became even stronger as Giroux gradually began to adopt what I would regard as a lucid and compelling style which makes a mockery of the claims made by some that his writing is not 
accessible. In all probability these detractors have read little of Giroux's vast oeuvre and have remained in a time warp as far as his output is concerned. The style has changed considerably since the early but still valid Theory and Resistance. A classic case would be one of his most recent works, Hearts of Darkness.

\section{Issues Concerning Democracy or Lack of it}

Hearts of Darkness (Giroux, 2010b) is a compelling read which nevertheless can have a chilling effect on the sensitive reader. In a style somewhat reminiscent of Chomsky, and to a certain extent of Giroux's great friend Donaldo Macedo (see for instance The Pedagogy of Big Lies), Giroux overwhelms the reader with documented accounts of the kind of callous and clinical practice he denounces, retaining the momentum throughout his narrative with the escalatory: 'it gets worse'. The various forms of torture (including water-boarding and human mopping of excrement) that he describes in great detail are, he underscores, targeted also at innocent youth and children, occurring in various US satellite countries (including Mubarak's Egypt) as part of America's seemingly never-ending 'War on Terror'. It is symptomatic of a society which determines who is worthy of living and who is disposable; whose life support system is to be strengthened and whose is to be cut loose (this applies also to the destitute and the sick, waiting for, say, a transplant, inside the United States itself, as Giroux makes clear in a variety of sites, including podcasts of radio interviews). We seem to be having a war waged on the foreign and home fronts. As for the war on both fronts, focused for the most part on 'real' or 'simply suspected' terrorists, this, make no mistake, was instigated by Bush, Cheney and their ilk.

\section{Obama's False Dawn?}

Despite his pre-electoral promises, however, President Obama continues to wage the very same war, retaining some of its 'legal legalities', including most recently the authorisation of a secret incursion into a sovereign state to summarily execute, without imprisonment and trial, no. 1 US public enemy Osama Bin Laden (and then dispose of the body at sea). Giroux warned readers, soon after Obama's election to the US presidency, of what to expect, almost as if to temper their enthusiasm:

$$
\begin{aligned}
& \text { Barack Obama takes office at a time of great uncertainty, a time when the conventional wisdom } \\
& \text { and old assumptions of free market fundamentalism are thoroughly discredited. At the same } \\
& \text { time, a new hope is taking shape, fueled by the need to reaffirm the democratic legacy of social, } \\
& \text { political, and personal rights through a reaffirmation of the discourse of governance and } \\
& \text { responsible politics and its connection to the language of democracy and the imperatives of the } \\
& \text { public good. And yet the optimism that accompanied Barack Obama's election is gradually } \\
& \text { giving way among many progressives to either a deep sense of despair in light of his increasing } \\
& \text { political shift to the center or a doom-and-gloom cynicism in the face of economic crisis. } \\
& \text { (Giroux, 2009a) }
\end{aligned}
$$

Giroux's trenchant criticism of US politics after the hope generated by Obama's election is typical of his recent work. These later works (Giroux, 2010b) - in which Giroux builds on countless articles published in online reviews such as Truthout and occasionally Counterpunch - cover Obama's initial period as President of the United States. They are, of course, critical of some of the policies adopted thus far, which, in Giroux's view, appear, in many respects, to be a continuation of the Bush years.[1] The Bush years and the initial Obama years are ones characterised by the shredding of the social contract. They constitute an era in which democratic considerations are placed in cold storage to make way for a new type of authoritarianism.

\section{Authoritarianism Eclipsing Democracy}

The authoritarianism makes its presence felt not only through figures in military regalia, visible though these may be in an age of increasing militarisation, but also through the all-pervasive images of corporate power that characterise several aspects of our lives, comprising entertainment, youth culture, public schooling and universities. It is an authoritarianism that is mediated by a 
number of developments (see chapter 1 in Giroux, 2005a, pp. 30-108). These include: the neoliberal state changing its traditional role, in this context, to one that unfurls the infrastructure for capital mobility and unleashes its ever-present repressive mechanisms on those who fall victim to the vagaries of the market - unemployed youth and adults, migrants, the poor in general, etc; the constant generation of a culture of fear (especially in the wake of $9 / 11$ and other terrorist attacks); a strong sense of nationalism in keeping with a media-contrived 'imagined community' of 'patriotic' 'Americans'; an all-pervasive presence of prisons (predominantly private and in need of a market) and security officers ensconced in such places as schools; a glut of media images, including popular cultural images, which render militarisation palatable and military enrolment attractive; a constant blurring of the traditional dividing line between religion (see chapter 5 of Giroux, 2006f) and state. With respect to the last point, the wars abroad and at home, waged through authoritarian policies in the latter case, are justified by a language that not only smacks of Orwellian 'doublespeak' (see chapter 7 in Giroux, 2006f) - 'enhanced interrogation techniques' is used for downright callous torture, for example - but also is couched in religious fundamentalist terms.

The final characteristic of this new authoritarianism is that it is mediated by a process of corporate encroachment on everyday life, very much a feature of the first mediation referred to earlier, the one concerning neoliberalism. Neoliberalism renders persons simply producers and consumers and not social actors who can engage in and help develop the public sphere and publicly and collectively challenge the forms of authoritarianism taking root.

Culture becomes a battlefield of contestation in this scenario, as Giroux has been consistent in emphasising throughout his oeuvre, taking his cue from many writers here, including Gramsci and Adorno. He does so without overlooking political economic considerations, and while perusing a variety of texts ranging from the print media to film, each constituting forms of what he calls 'public pedagogy' (Giroux, 1999, p. 4). This concept best captures his attempt to extend the notion of pedagogy well beyond the important though very limited context of schooling. Every relationship of hegemony is an educational relationship, Gramsci would tell us, and, in this respect, Giroux engages a tradition that comprises the work of not only Gramsci (Giroux, 1980a,b, 1988) but also Theodor Adorno, Raymond Williams, Walter Benjamin, and more recently Stuart Hall, Paulo Freire, Maxine Greene, Homi Bhabha, Noam Chomsky, Roger I. Simon, bell hooks, Howard Zinn, Judith Butler, Nancy Fraser and Zygmunt Bauman, to name but a few.

Giroux has always viewed the cultural terrain as a vehicle for the shaping of subjectivities. It also contributes to the cultivation of desires through a 'pedagogical' process, the structuring principles of which are political (Giroux \& Simon, 1989, cited in Giroux, 1992, p. 188; Giroux \& Simon, 1989, p. 10). It is also a vehicle for the production, enactment and circulation of social practices, to echo Stuart Hall (Giroux, 2000a, p. 9). Culture, as Gramsci argued, is a very important vehicle for the development, contestation and renegotiation of the present hegemonic arrangements (Giroux \& Simon, 1989, cited in Giroux, 1992, p. 186; Giroux \& Simon, 1989, p. 8).

\section{Gramsci and Freire}

One of Giroux's earliest pieces is an article on Gramsci in Telos. Similar essays on Gramsci appear in later works (Giroux, 2000b, 2002). Giroux uses Gramsci and others to avoid limiting his work to simply 'ideology critique', since he takes on board the Italian's emphasis that ideology is never $100 \%$ false but contains partial truths. It contains elements which connect with people's everyday preoccupations and experience which populists and right-wing governments prey on to win over the vote or support of those whose interests they do not represent. Any oppositional discourse which overlooks this element within ideology that 'really makes sense' misses the point. This aspect would, according to a Gramscian conception, serve as the basis for the conversion of common sense into good sense. The task of critical pedagogy is to analyse with learners, collectively and systematically, the matter at issue to develop a coherent vision for reconstruction . This lies at the heart of a Gramsci-inspired critical pedagogy, and one would do well here to follow the lead taken by Stuart Hall (1988) in his use of Gramsci's notion of hegemony for his analysis of Thatcher's third successive electoral victory in 1987 (see Showstack Sassoon, 2009, p. 80). Giroux, it occurs to me, draws on these critical insights to help map out terrains in which people can act as social agents and 'transformative intellectuals' (Giroux, 1988). Social agents engage 'in a 
commitment to a form of solidarity that addresses the many instances of suffering that are a growing and threatening part of life in America and abroad' (Giroux, 1997a, p. 104). The issue of solidarity underlines the collective dimensions of knowledge, which entail 'the necessity of working collectively alongside the oppressed' (Giroux, 1997a, p. 104).

It is for this reason, in keeping with a nuanced conception of 'ideology', that Giroux does not confine himself simply to questions of textuality, ideology critique and signification (Giroux, 2000a, pp. 131-132). He must have regarded such preoccupations as simply distracting academics from taking on the role of public intellectuals who can address a wide readership or audience with insights for the utopian vision of a radical democracy, characterised by equity and social justice. They would engage in a pedagogy which links the political and the personal.

These concerns emerge quite clearly in works of the last twelve years or so (Giroux 1999, 2000a, b, 2001, 2004, 2005a, 2004, 2006c, e), to which I will devote the bulk of my attention in this article. These books will together provide the springboard for a discussion of related themes broached in earlier works (Giroux, 1994a, 1996, 1997a, b; Giroux \& Shannon, 1997).

The corpus of his work is indeed massive, with other works being completed at the time of my writing this piece. One major source of influence on Giroux is Paulo Freire, about whom he kept writing even most recently (a piece in Truthout, a book for a series on Freire [Giroux, 2011a] and a recent book about teachers [Giroux, 2012]).

Giroux found, in Freire's work, 'an attempt to take seriously the relationship between education and social change, to dignify the subject of learning, to be attentive to questions of contextualisation, to link education to particular forms of individual and social empowerment' (Giroux, 2006b, chapter 4). Freire's pedagogy that was 'forged in a kind of struggle to link education to justice' remains relevant, according to Giroux, in this day and age since it provides the antithesis to the dominant education policy that characterises the new 'authoritarianism' in the United States with its 'militarism', 'market fundamentalism', and a 'horrible religious fundamentalism that has nothing to do with genuine religious compassion and insight' (Giroux, 2006b, chapter 4).

Giroux sees, as many do, this religious fundamentalism (chapter 5 in Giroux, 2006f) as coexisting, almost naturally, with the kind of authoritarianism that he inveighs against. It must be said that Freire's pedagogy too has religious overtones, but they are mostly linked to the social justice-oriented Prophetic Church as opposed, in Cornell West's terms, to the 'church of empire', the 'Constantinian Church' [2], with its many variants, including that which mediates the present American Empire's 'new fascist' authoritarian policies. Freire's pedagogy is one in which, according to Giroux, 'the subject is confirmed' and 'learning is linked to questions of critical engagement' (Giroux, 2006b, chapter 4).

Thanks to the perennial alternative discourse that he provides, Freire continues to serve as a resource that, on Giroux's own admission, has consistently nourished his work from the early stages till the present day (Giroux, 2006c, d).

\section{Social/Cultural Reproduction and Resistance}

Giroux's early works comprise writings that engaged the then dominant theories of social/cultural reproduction and resistance in education, very much inspired by neo-Marxist writings (Giroux, 1981a [3], 1983). Giroux later collaborated with sociologist Stanley Aronowitz in roughly the same area (Aronowitz \& Giroux, 1985). Giroux drew a lot from the reproduction/production/ resistance paradigm. He, after all, continues to 'engage the Marxist tradition' (Giroux, 1992, p. 13), seeking to add a 'critical cultural politics' (Giroux, cited in Torres, 1998, p. 136) dimension to the neo-Marxist educational paradigm as a means to help revitalise it; he is most wary of turning Marxism into some kind of 'ideological church'. In the process, he draws on Paul Willis's ethnographic work and that of many others, notably the writings of key Frankfurt School figures, particularly work relating to the emancipatory phase rather than that belonging to the later 'negative dialectics' period. Adorno, for instance ('Education after Auschwitz'), continued to remain a source of reference even in Giroux's more recent works (Giroux, 2005a) focusing on the trampling on human rights in Guantanamo Bay, Abu Ghraib and other countries (e.g. Egypt) where torture (legal illegalities) is 
'subcontracted' (Giroux, 2010b).[4] He is also adamant that the Left requires a new language in these troubled authoritarian times:

As the Right wages a frontal assault against all remnants of the democratic state and its welfare provisions, the progressive Left is in disarray. Theoretical and political impoverishment feed off each other as hope of a revolutionary project capable of challenging the existing forces of

domination appears remote. (Giroux, 2005b)

And, of course, in addition to the above, he devotes lots of attention to, and has contributed to, cultural studies. Ernst Bloch's Principle of Hope is the important source of influence here. Certain strands of postmodern literature also made their presence felt in a number of works in which popular culture was conceived of as an important area of enquiry (Giroux \& McLaren, 1989; Giroux \& Simon, 1989; Aronowitz \& Giroux, 1991). In addition to these areas, one notices the influence of feminist literature (Giroux, 1991), postcolonial studies (Giroux, 1992), and poststructuralism. Quite influential is the work of Michel Foucault. These influences continue to inform his work, which remains emancipatory in its main thrust and centres around issues concerning social justice.

\section{Cultural Studies}

Giroux's engagement with cultural studies is a recurring feature of his writings (Giroux \& Searls Giroux, 2004):

Culture not only mediates history, it shapes it. We argue that culture is the primary terrain for realizing the political as an act of social intervention, a space in which politics is pluralized, recognized as contingent, and open to many formations. (p. 95)

Giroux seeks to bring a strong cultural studies dimension to educational thinking and a pedagogical dimension to cultural studies itself. What rendered cultural studies so important to education, in Giroux's eyes, is the fact that it deals with a whole range of pedagogical agencies. These 'public pedagogical' agencies constitute the terrain where hegemony is both shaped and challenged. It can be challenged by virtue of an oppositional discourse, a discourse of transgression, a form of 'living dangerously' (Giroux, 1993), if you will, occurring 'in and against' institutions such as universities (Giroux \& Searls Giroux, 2004) and the film industry (Giroux, 2002). None of these is monolithic. Educators are called upon to engage in these sites of struggle to act as cultural workers, transformative intellectuals and oppositional public intellectuals. These intellectuals act not alone but in solidarity with others. Their collective knowledge and actions presuppose specific visions of public life, community, and moral accountability (Giroux, 2000a, p. 141).

How can educators respond to Giroux's challenge of adopting a cultural studies approach (see e.g. Giroux \& Searls Giroux, 2004)? One way of ensuring that the cultural studies area becomes a meaningful political pedagogical practice, and not an enclave for those indulging in 'radical chic', is by extending it to the area of adult and community education/action. Raymond Williams reminds us (Williams, 1993, p. 260) that adult education provided the context for cultural studies to emerge in its British versions. For Giroux, adult education would constitute just one of many settings for cultural studies and education. Education's terrain is broad enough to comprise numerous pedagogical sites that extend beyond formal education. Education is thus the prerogative not only of professional teachers - whom he addresses in a number of books (see Giroux, 2012) - and academics, but also of a broader range of cultural workers. This partly explains why Giroux gradually moved from writing about public schooling to engaging in lengthy discussions of broader social issues, such as war and corporate power, and various forms of cultural production, such as film, cartoons and media news packages. This represents a marked contrast with Giroux's early work around schooling, although he addresses the crisis of schooling and teacher redundancy in his latest work (Giroux, 2012), in the context of a crisis of public values in the USA which he contrasts with the situation in Europe and especially the indignados in Spain and Greece, where the treachery of 'casino capitalism' is confronted head on. I would add (Mayo, 2012b) that teachers are among the victims of the 'debtocracies' in Europe as public employees who had their salaries cut and, in certain places, have featured prominently in anti-neoliberal protests, including the kindergarten 
teachers who joined university students and others in Vienna. For Giroux, however, public pedagogy occurs through various sites and practices.

Many of Giroux’s works provide critical analyses of the broader pedagogical function of several important cultural sites, characterised by an increasing degree of corporate encroachment. These include corporations such as Calvin Klein (Giroux, 1997b; 2000b, pp. 74-81) and the familyrun Treviso (Italy) firm Benetton (Giroux, 1994a, 2006a). He also provides an incisive analysis of the loss of innocence occurring through such forms of 'anticipated adulthood' as child beauty pageants (Giroux, 2000b, pp. 39-64; 2006f). These pageants, it has to be said, feature young girls attending schools both outside and inside the USA. This American practice, as with other 'Made in the USA' practices, has been transported elsewhere.

Giroux's later work is also well known for its trenchant analyses of globally venerated 'Made in the USA' products. His dissection of the Disney Empire once aroused mixed feelings among graduate students at my home university, for they regard Disney as having been one of their childhood's key sources of 'innocent pleasure'. Giroux's exposure of the insidiousness of the corporate, imperialist agenda, veiled by the spectacle of innocence and make-believe, ever so appealing in this age of the spectacle, including the brutal spectacle [5], must have provided these students with a rude awakening. The study combines cultural criticism with a strong political economic analysis. Giroux's analysis, which exposes the extent of the corporate reach, provides insights into exploitative labour relations in certain parts of Disney's work venues.

\section{The Film Industry}

The film industry has been a lifelong fascination for Giroux (Giroux, 2006f). In fact, he has written numerous film reviews that appear in many of his books. The films covered include not only the numerous Disney blockbuster cartoons but also Dirty Dancing (Giroux \& Simon, 1989); Dead Poets Society (Giroux, 1993); Boyz $n$ the Hood and Juice (Giroux, 1994b; Giroux, 2006a); Good Morning Vietnam, Pretty Woman (Giroux, 1999; 1994a) and Fight club (Giroux, 2001).

Giroux demonstrates how some of the images projected in these films also serve as public pedagogies (Giroux, 2001, p. 75). These pedagogies resonate with broader social and political issues and this resonance has a bearing on the construction of our subjectivities, sensibilities and political dispositions. They would include such elements as: the racist misrepresentations of Arabs and the Orient (in Said's terms) in Aladdin; degenerate images of youth in 'heroin chic' adverts and such films as Dangerous Minds, The Substitute I and High School High (Giroux, 2000b, 2006a); racially discriminating overtones in the language of The Jungle Book; sexism in Pretty Woman; violence and machismo in Fight Club; and the complex set of representations in black films of the 1990s, such as Boyz $n$ the Hood and Juice (Giroux, 2006a, pp. 105-108).

\section{War on Youth and Children}

Henry Giroux's comprehensive analysis comprises the scouring of different sources of pleasure and public pedagogy to reinforce one overriding thesis. The overarching thesis is that of a war being waged against children and youth (especially marginalised and 'disposable' youth such as blacks, indigenous, and working-class youth). The war is being waged against precisely those people who, in Giroux's view, should hold out the promise of a better future. Youths and children are made the subject of relentless attacks that take several forms, including coercion, demonisation, militarisation and commodification (through corporatist encroachment) within a New Right scenario (see, for instance, Giroux, 2009c).

Among the hardest hit, in Giroux's view, are undoubtedly the children and youth of those countries that are the victims of senseless wars waged by the USA and its allies targeting civilians (notably in Afghanistan and Iraq) and who die in their thousands, or are permanently maimed, through what is perversely dubbed 'collateral damage'. Giroux's numerous writings on the subject are overwhelming in terms of the presentation of data indicating the deaths and injuries suffered by youth and children not only as a result of bombardments by US forces and their allies but also through the indirect effects of the destruction of public infrastructure in Iraq, in the 1991 Gulf War, which led to malnutrition and deadly diseases (Giroux \& Searls Giroux, 2004, pp. 70, 75, 76). He 
returns to this theme in more recent op-ed columns in reviews such as Truthout and Counterpunch, as well as in his very recent Hearts of Darkness (Giroux, 2010b), a book recently promoted by Truthout itself as part of its reader donation campaign.

\section{Withdrawal of Social State}

The above refers to a situation brought about by the military-industrial complex that has rendered militarism the solution to world disputes caused in part by unequal access to the world's resources. What makes this situation worse is the fact that such wars, particularly those couched as 'wars on terror', provide legitimacy to stringent social measures and Orwellian 'Big Brother' surveillance strategies on the home front in the interest of pushing through neoliberal policies whereby market relations, deregulation, consumerism and privatisation are privileged at the expense of state interventions to safeguard social inclusion and solidarity. These latter elements become dirty words, and those who cannot produce and consume are left to flounder by the wayside in a manner that was shockingly revealed to the world at large in the wake of Hurricane Katrina.

Defined primarily through a discourse of 'lack' in the face of the social imperatives of good character, personal responsibility, and hyper-individualism, entire populations are expelled from the index of moral concerns. (Giroux, 2006d)

This situation had been apparent to all who wanted to see well before then, as one of my first visits to the USA, a trip to San Francisco to participate in the 1992 AERA Meeting, made plainly clear to me: Latinos/as and First Nations people lying around in destitution.

\section{The Carceral State}

The situation, as Giroux drives home time and time again, is compounded by the emergence of a carceral state that spends more on prisons, to discipline or 'weed out' the victims of such neoliberal policies', than it does on public education. Giroux shows, in common with such writers as Chomsky and Macedo, how there are more black youths in prisons than in public education institutions - a shocking revelation that attests to a war on children and youth being waged not only in Afghanistan and Iraq but also on the home front.

Punishment, incarceration, and surveillance have come to represent the role of the new state.

One consequence is that the implied contract between the state and citizens is broken, and social

guarantees for youth as well as civic obligations to the future vanish from the public agenda.

(Giroux \& Searls Giroux, 2004, p. 74)

This process has, as Giroux has been forcefully demonstrating in Truthout and elsewhere, reached into public schools which are being run like prisons. Security guards often use heavy-handed tactics (what should security guards be doing inside schools anyway?) for such perceived minor infringements as not having a shirt tucked in. This is a classic example of Althusser's statement that there is no such thing as a pure ideological state apparatus (ISA) or repressive state apparatus (RSA). Even his main ISA - the school - has been shown to be serving, in Giroux's recent writings, a repressive function. Both ISAs and RSAs are often inextricably intertwined, as in the case of high schools and heavy-handed security guards. And it would be no stretch to argue that the apparent violence perpetrated is itself symbolic because it signals to the students something about their identities, perhaps that of potential criminals who can eventually be incarcerated, a signal that is very much in keeping with the function of an ISA (see Mayo, 2011).

One ought to remark that carceral states await the victims of neoliberal policies worldwide, notably those countries that are serving as 'first port of call' for immigrants from Africa and Asia fleeing poverty, starvation (exacerbated by structural adjustment programmes), lack of employment, droughts caused by climate change, despotic regimes (often western backed) and internal wars fuelled by a potent western-based arms industry (the USA is the major exporter of arms, Giroux reminds us). The carceral settings awaiting such hapless victims include detention centres (closed and open centres) where immigrants are kept for long periods prior to decisions being taken regarding whether they should be allowed in as refugees or repatriated. And neoliberal 
policies make their presence felt in these contexts, since the provision of a grossly underpaid 'reserve army' of immigrants, including illegal immigrants, serves to depress local wages.

Needless to say, young people, mainly youth and children, feature prominently in this reserve army, with many people of their age having lost their lives in the process of crossing over from, say, the shores of northern Africa to southern Europe, in crowded dinghies. Drowning occurs frequently. Between July and September 2006, no less than 8849 clandestine immigrants landed in Italy, of whom 168 were discovered dead while 144 were dispersed.[6] The Spanish newspaper El Pais reported that 490 bodies of immigrants were recovered from the African and Spanish shores. The same newspaper reported that the Red Cross and Mezzaluna Rossa believe that the number of clandestine migrants who disappeared by that time amounts to between 2000 and 3000.[7]

\section{War on Different Fronts: home and abroad}

As far as the link between Iraq and the USA goes, Giroux demonstrates how the massive cost of financing the war in Iraq is borne by the American people themselves, since this is partly made good by cutbacks on the social wage that results in lack of funding for social programmes, including public education programmes, public health schemes and so forth. The brunt is thus borne by the poor who, once again, are treated as disposable beings: the 'human waste disposal' segment of American society, to use Zygmunt Bauman's term (Bauman, 2006). What renders the burden heavier is the fact that the Bush administration unabashedly provides the wealthiest segment of US society with huge tax cuts as part of its 'economic stimulus' policies (Giroux \& Searls Giroux, 2004, p. 80).

While $\$ 723$ billion dollars are allocated for tax cuts for the rich, state governments are cutting a total of $\$ 75$ billion in health care, welfare benefits, and education. (Giroux \& Searls Giroux, 2004, p. 59)

Giroux therefore demonstrates, throughout numerous works (Giroux, 2004, 2005a, 2006a; Giroux $\&$ Searls Giroux, 2004), that a war on the poor and disenfranchised is being fought on two fronts, the foreign and home front. In the latter case, it takes the form of 'the silent war at home', in that:

the Iraq war and the war against terrorism are being financed from cuts in domestic funding on health care, children's education, and other public services. (Giroux \& Searls Giroux, 2004, p. 57)

The post-Katrina images provide testimony to the 'silent' war being waged on the home front, in which youth and children, those who hold out the promise for the future, feature among the greatest casualties (Giroux, 2006c, d). The places which have been hardest hit were very much the target of militarisation (to prevent looting) and social engineering. They also served as laboratories for market reforms (Giroux, 2006c, p. 59). These reforms generally lead to gentrification, as a number of international experiences have been showing time and time again. In Giroux's terms, this situation is symptomatic of a new biopolitics devoid of 'democratic principles, practices and values and scornful of the social contract' (Giroux, 2006c, p. 63).

Sites of public pedagogy continue to provide legitimacy for such polices, especially through the politics of representation of destitute youth underlying the unsavoury images referred to earlier (see Kellner, 2001, p. 143). These demonisation strategies justify cuts in spending on youth welfare and other social programmes, as well as denying crucial life-saving health services in certain states. Even students, the intelligentsia of today and tomorrow, are overburdened with cripplingly huge loans, and it is argued by one of Giroux's interviewers that by 2012 outstanding student loan debts will reach \$1 trillion in the United States (Giroux, 2011a, p. 2).

The war on children occurs, however, not only through 'retrograde policy and the dismantling of the welfare state, but also through the pervasive glut of images that cast them as the principal incitements to adult desire', as in the case of the child beauty pageants (the commodification of young female bodies) referred to earlier, which, in certain cases, can result in tragic deaths at the hands of paedophiles (Giroux, 2000b, p. 63). The war is waged on several other fronts.

For instance, the war on black youth, who feature among the greatest casualties of this onslaught, is discussed in several places, notably in Fugitive Cultures (1996) and, as indicated, in more recent work (Giroux, 2006a, chapter 6). The operative term in this context is 'zero tolerance', to 
which Giroux dedicates several discussions in his later writings, notably chapter 2 of Public Spaces/Private Lives. The whole theme of the carceral state relates to this notion, and what makes the situation worse is that black youth are often the target of a whole range of recruitment strategies, also involving popular culture devices, to swell the ranks of the military waging war both at home and abroad; joining the military represents for such youth a way out of the poverty to which they have been confined, a way out which alas often results in a similar dead end, this time taking the form of body-bags containing their remains being flown over from Iraq.

\section{Un-American Activities}

The situation of repression is compounded by the advent of a new McCarthyism which made its presence felt throughout US society (see Giroux \& Searls Giroux, 2004, chapter 1) and which spreads to the universities. Giroux speaks of faculty being intimidated from speaking publicly about social issues because of 'the increasing assumption in American society that any sort of critique' that speaks truth to power or 'calls official power into question is somehow perceived as unAmerican' (Giroux, 2011a, p. 1).

\section{Corporate vs. Public Time}

The war on children and youth is even more subtle and takes on a less blatant form. As Giroux indicates time and time again, it also comprises corporate culture's encroachment on all spheres of life. Capitalism constantly extends its reach in the quest for new markets and to draw more aspects of our existence into capitalist social relations of production. Public goods are converted to consumer goods, with citizenship being reduced to a two-dimensional aspect of our lives. From potentially social actors (see Martin, 2001, p. 5) engaging in the public sphere and availing ourselves of 'public time' - that is, the slowing down of time 'in order to question what Jacques Derrida calls the powers that limit "a democracy to come", "we are constantly reduced to being persons engaged in "corporate time" - that is, 'a notion of accelerated time in which the principle of selfinterest replaces politics and consumerism replaces a broader notion of social agency' (Giroux $\&$ Searls Giroux, 2004, p. 227). In the latter case, everything is carried out at speed and with technical efficiency, allowing little time for deep reflection and therefore praxis. This alternative pedagogy characterised by 'public time' would be akin to what Lorenzo Milani, of the School of Barbiana in Tuscany, Italy, calls 'la pedagogia della lumaca' (the pedagogy of the snail).

\section{Corporatisation of Schools and Universities}

While Giroux has extended his areas of analysis beyond schooling, he has not ignored the ongoing corporatisation of schools and universities (see Giroux, 2011b).[8] On the contrary, higher education has become a key theme in Giroux's writings (see, most recently, Giroux 2010d). This is understandable, given the massive changes being brought about in these institutions. These changes are also occurring in the European university context, in which I operate, especially through the so-called Bologna Process (intended for purposes of harmonising European qualifications).

Henry Giroux expresses concerns regarding the way corporations (including Disney) trade advertising rights in the schools' rest places and corridors for funds. These concerns should be heeded by educators and school principals/heads in other countries as they seek to make up for lack of funding occurring through neoliberal cutbacks by resorting to corporate sponsorship. Giroux's discussions concerning the university's corporatisation are also instructive. The marketplace ideology and a technical rationality are taking precedence, in these institutions, over concerns with providing the tools for active citizenship in a participatory democracy in which people learn and develop the knowledge to exercise their 'right to govern'.

The commodification of higher education (see also chapter 6 of Giroux, 2006f) is manifest in a variety of ways: through increasing bureaucratisation; the erosion of the humanities; the transformation of schools of education into places where one learns 'what works' rather than places where one engages in critical reflection; the transformation of the role of university 
presidents and deans from that of academic leader to that of a CEO and minion of industry; the exaltation of the notion of 'entrepreneurship', part of the higher education doxa; rendering university research dependent on corporate funding (Research \& Development), with ramifications for intellectual property and dissemination of results; instrumental knowledge in lieu of knowledge that promotes critical thinking; reducing tenured staff and employing part-time adjunct faculty who slave away at teaching with next to no time for research and engagement in the public sphere. Many universities, within a classified system involving elite research-oriented (a select few) regional or mainly teaching institutions, are increasingly becoming glorified training agencies evaluated for their contributions to the economy rather than for their contribution to the creation and revitalisation of democracy (Giroux \& Searls Giroux, 2004; Giroux, 2007). Giroux also underlines that universities, and especially the research-based ones, are increasingly constituting an important component of the 'military-industrial-academic' complex' (Giroux, 2007).

Universities and other institutions of higher education have been undergoing changes that reflect the corporate world's preference for accelerated time in lieu of that sense of 'public time' that was once associated with schools and universities as public spaces that provided the right setting for reflection and assimilation. This was the sort of time which was part and parcel of the now defunct, albeit elitist, Humboldt tradition in Europe, a tradition which is also giving way to a more 'employability oriented' and 'entrepreneurial' university, especially as a result of the EU's higher education discourse (Darmanin, 2009; Mayo, 2009a).

\section{Academics and Students: public intellectuals and movement activists}

And yet, as Giroux himself points out in an interview (Giroux, 2011a), Europeans have been reacting to this 'neoliberalisation' of the university and other higher education institutions.

Many Europeans are not accepting this state of affairs. If the old university is elitist and not in tune with present-day realities, it requires a transformation which renders it more democratic and expansive in conception and not lean in the same way that the state is said to be 'lean' only in so far as social programmes are concerned (Mayo, 2011). Criticality, an ingredient of a truly democratic critical citizenship becomes a casualty in these circumstances. And students in Austria, Hungary and other parts of central Europe have understood this, often joining forces with academics to mobilise against this state of affairs. The mobilisation often becomes international, with protesting Hungarian students blocking a train of higher education experts making their way to Vienna for a meeting, as students in both countries coordinated their protest efforts. Proposed reforms of universities in Italy by the right-wing Berlusconi government, and communicated by Minister Gelmini, led to students occupying the institutions in various parts of the peninsula and islands. This echoed what happened in Greece on 8 June 2006, when 20,000 students took part in the largest student march for two decades, which made its way through downtown Athens. Higher education becomes a public space worth fighting for. This provides the context for students and academics to stand out not only as a social movement and forge alliances with other movements, as was the case in Vienna, when students joined forces with kindergarten teachers (the two ends of the education spectrum), but also as public intellectuals. In addition to Giroux's notion of the academic as public intellectual we can also conceive of the higher education student as public intellectual. There are many models to follow, from among students worldwide, in acting as opinion leaders for a transformation in society. One can mention, in this context, Carlo Alberto Libanio Cristo (later known as Frei Betto) in Brazil during the military dictatorship (he was imprisoned twice). As for Europe, I would mention Mario Capanna, who made his name when he was a student at the Sacro Cuor Catholic University of Milan and later as leader of Democrazia Proletaria (Proletarian Democracy). Capanna was a key figure in the Italian student movement of the 1960 s.

The neoliberal reform of universities offers a splendid opportunity for academics and students to continue to join forces as 'public intellectuals' and not only denounce university neoliberal reform but also turn what is already a public issue (education as a public good) into a broader allencompassing public issue, connecting this reform with the broader neoliberal reforms that have been sweeping across countries and continents and which have turned society into one large marketplace. 


\section{Engaging the Academy}

Given the increasing corporatisation and commodification of what were once important public spaces, it is heartening to see that there are public and specific intellectuals who seek ways and means of extending their roles as educators outside the university. They forge alliances with activists and popular educators in different social sectors. In doing so, they face the risk of missing out on opportunities for career advancement since community involvement is rarely rewarded in department reviews or research assessment exercises. Quite laudable are the initiatives by academics to engage the academy in popular education (see the various contributions to Thompson, 2000). These initiatives allow educators, in and outside the academy, to become, in Giroux’s terms, 'border crossers' (Giroux, 1992).

As border crossers, academics act beyond the traditional contours of their work to join forces with others to help generate a substantive democracy, regarded by Giroux, Freire and others as a dynamic and an ongoing process. Giroux's own predilection for writing about the themes of his books in the accessible media, from newspapers in Canada such as the Toronto Star to the online In These Times, Counterpunch and Truthout (he serves on the board of directors), as well his provision of video interviews accessible on such widely diffused Internet sites as YouTube, are indications of his efforts to walk the talk in engaging as a public intellectual. Following Pierre Bourdieu and others, he recommends this role for university-based academics and other intellectuals in many of his works. He laments the demise of this type of intellectual in today's 'censored' world with its penchant for celebrity culture (Giroux, 2010d, 2011a). One also ought to remark about the very accessible language in which most of his works are written. This strikes me as an important point to make, given that critical pedagogy is often criticised indiscriminately for its obscure and 'esoteric' language that renders it far removed from the language of social activists, teachers and other cultural workers operating 'in the trenches'. Giroux is wary of romanticising 'the trenches', so to speak, where one can easily lapse into the kind of 'tried and tested' routine activities without opportunities for reflection for transformative action. An unexamined life is a life not worth living, as the Socrates line that any beginning philosophy student would recite goes.

\section{Academic Disengagement}

As far as academics are concerned, they too are not to be romanticised, according to Giroux, who is well aware of the presence of several intellectuals adopting positions that ultimately do not challenge the status quo. He recently stated, 'I am also disturbed by the increasing political insularity of the academy and the increasing refusal of faculty to connect their work with larger social issues. Many of them retreated into academic specializations and an arcane language that made them irrelevant to the task of defending the university as a public good' (Giroux, 2011a, p. 1). Much has been written on this aspect of academic life, where the lure of prestigious and lucrative 'technicist' career opportunities can easily lead academics to go with the flow of corporatisation and academic entrepreneurship, buying into the dominant ideology that renders industry the panacea for the survival and relevance of the university. One need therefore not rehearse the literature. One ought, however, to refer to two types of intellectuals, among the many targeted by Giroux in his writings. There are those who appropriate left-wing revolutionary figures by providing domesticating (mis)readings of their works to reinforce conservative or at best nonthreatening liberal positions regarding schooling and other social aspects. E.D. Hirsch came in for some scathing criticism for his misuse of Gramsci's writings.

Giroux is also scathing in his criticism of the type of intellectual who, in Foucault's terms, confines his or her leftist posturing to 'trading in polemics', a form of what Giroux regards echoing a favourite phrase from Marcuse - as 'scholarshit':

Lost here is any attempt to persuade or convince, to produce a serious dialogue. All that remains are arguments buttressed by an air of privileged insularity that appear beyond interrogation, coupled with forms of rhetorical cleverness built upon the model of war and unconditional surrender, designed primarily to eliminate one's opponent but having little to say about what it means to offer alternative discourses to conservative and neo-liberal efforts to prevent the democratic principles of liberty, equality, and freedom from being put into practice in our schools and other crucial spheres of society. (Giroux, 2000a, p. 14) 


\section{Politics of Hope}

Cynicism and nihilism are rife in today's world and often generate a culture of derision directed at any attempt to drive home the point that another world is possible. This nihilism and cynicism reflect a politics devoid of hope. Giroux argues for a politics of hope in the manner of such other radical intellectuals as Paulo Freire and Zygmunt Bauman.

Giroux advocates not a messianic hope but an 'educated hope' based on a critique of the present. This 'educated hope' should, according to Giroux, be characterised by ongoing critique and renewal. In Freire's words, it should involve a process of 'annunciation' and 'denunciation' in favour of a more radically democratic public sphere where democracy, pedagogy and human agency are connected (Giroux, 2001, p. 125). Viewed this way, Giroux's vision is utopian. His is an anticipatory utopia, prefigured not only by critique of the present but also by an alternative pedagogical/cultural politics underscoring 'issues of value, ethics, meaning, and affect' (Giroux, 2001, p. 139).

He further goes on to echo his colleague and former co-author Stanley Aronowitz in calling for the emergence of a third party, a radical party, in the United States that promotes a new biopolitics, and a multifaceted politics at that, which 'must not only address the concerns of the middle classes but must also join with 'rank and file activists of trade unions, women's organisations, environmental and ecology movements, various factions of the freedom movements for Blacks, Latinos, Asians, and other oppressed peoples, and the anti-war and global justice movements to expose the illusion of democracy in the United States' (Giroux, 2006c, p. 67). Freire's insights on the nature of the relationship between party and movements - the party should approach them without trying to take them over (Freire, in Escobar et al, 1994, p. 40) - strike me as being most pertinent and instructive in this context.

Giroux calls for more than this. He calls for an 'Oppositional Global Politics' based on an assessment of the emergence of the different forms of oppositional movements in various parts of the world, not least the centre-left governments in Latin America (Giroux, 2006e, p. 81). More recently we are witnessing the pro-democracy movements throughout the Arab world fighting oppressive regimes through a variety of means, including digital means (Herrera, 2011), in what has the makings of a pan-Arab youth movement. Giroux has been making frequent references to the situation in North Africa and the Middle East in his contributions to Truthout and other electronic reviews.

\section{Conclusion}

Henry Giroux's oeuvre is vast and varied and is characterised by different stages in the evolution of his thought. The amount of writing is overwhelming and one develops the sense that similar issues are constantly being developed, expanded and revised across a number of books that represent a specific stage in the evolution of his thought as an academic and public intellectual where accessibility of language is combined with rigorous and systematic thought. His works no doubt represent a bleak picture of the times in which we live, in which a 'new fascism', predicated on religious fundamentalism and the 'passion of the Right', and the formulation of global military and local surveillance strategies, is no longer nascent but firmly entrenched. Even Obama's election seems to come across, despite the significance of what it represented in US race-relations history, as a possible false dawn.

This notwithstanding, Giroux’s writings are, like those of Paulo Freire and Zygmunt Bauman, governed by a sense of hope. It is the hope of one whose work stimulates the reader to imagine the world not as it is now but as it can and should be.

\section{Notes}

[1] These criticisms of situations connected with present-day America are made in a variety of writings, notably 'op-ed' columns on topics such as the politics of lying (Giroux, 2009a), violence in schools $(2009 \mathrm{~b}, 2010 \mathrm{~b})$ and the disruptive proto-fascist practices meant to undermine social reforms that the new president seeks to introduce (Giroux, 2009d). 
[2] See Cornell West in an exchange with Toni Morrison, focusing on Mel Gibson's The Passion of the Christ, where he draws the important distinction between the Constantinian Church, of which the dominant American church is the legatee, and the Prophetic Church: http: / / www.youtube.com/watch?v=fjifj_PZONo\&mode=related\&search=. On the subject of the Prophetic Church, as opposed to the Traditional and Modernizing churches, see Paulo Freire's discussion in The Politics of Education (Freire, 1985), for which Giroux wrote the introduction (Giroux, 1985; also reproduced in Giroux, 1988) highlighting the liberation theology underpinnings of Freire's pedagogical politics characterised by the 'language of critique' and the 'language of possibility'. See the section in the introduction with the title: 'Liberation Theology and the Language of Possibility'.

[3] See also Giroux, 1981b and chapter 1 of the most recent Giroux anthology (Giroux, 2006a).

[4] As always, there is no substitute for reading the original sources. However, anyone seeking a comprehensive review of Henry Giroux's early work should refer to Ronald G. Sultana (1985). For two excellent detailed analyses that comprise Giroux's later work, see Kellner (2001) and Robbins (in Giroux, 2006a).

[5] These 'brutal spectacles' occur through alternative uses of the media (including the replaying of the planes' dramatic crashing into the Twin Towers and bestial beheading scenes shown on the Internet) to indicate the vulnerability of the West and the bio-politics of its sovereignty (Giroux, 2006e, p. 55).

[6] Source: http:/ /www.stranieriinitalia.it (Ansa news).

[7] Source: Ansa (Madrid), 28 August 2006. I am indebted to Melita Cristaldi, from Catania, Italy, for pointing me to the sources in notes 6 and 7.

[8] The phenomenon of corporate involvement in education is occurring in various parts of the world. Mary Darmanin (2002), for instance, provides a detailed analysis of HSBC's involvement in education in Malta, my home country.

\section{References}

Aronowitz, S. \& Giroux, H. (1985) Education under Siege: the conservative, liberal and radical debate over schooling. South Hadley, MA: Bergin \& Garvey. http:/ / dx.doi.org/10.4324/9780203222034

Aronowitz, S. \& Giroux, H. (1991) Postmodern Education: politics, culture and social criticism. Minneapolis: University of Minnesota Press.

Bauman, Z. (2006) The Crisis of the Human Waste Disposal Industry, in D. Macedo \& P. Gounari (Eds) The Globalization of Racism. Boulder, CO: Paradigm.

Darmanin, M. (2002) Opportunism of the Glocal: Malta's educational policies, International Studies in Sociology of Education, 12(3), 277-302. http: / / dx.doi.org/10.1080/09620210200200094

Darmanin, M. (2009) Further and Higher Education Markets' Cushions: portability of policy and potential to pay, International Studies in Sociology of Education, 19(3), 175-201. http://dx.doi.org/10.1080/09620210903424477

Escobar, M., Fernandez, A.L. \& Guevara-Niebla, G. (with Freire, P.) (1994) Paulo Freire on Higher Education: a dialogue at the National University of Mexico. Albany, NY: SUNY Press.

Freire, P. (1985) The Politics of Education. South Hadley, MA: Bergin \& Garvey.

Giroux, H. (1980a) Essay Review of Antonio Gramsci: conservative schooling for radical politics by Harold Entwistle, Telos, 45, 215-225. http:/ / dx.doi.org/10.3817/0980045215

Giroux, H. (1980b) Gramsci, Hegemony, and Schooling (Review Symposium), British Journal of Sociology of Education, 13(3), 215-225.

Giroux, H. (1981a) Ideology, Culture and the Process of Schooling. Philadelphia: Temple University Press.

Giroux, H. (1981b) Hegemony, Resistance and the Paradox of Educational Reform, Interchange, 12(2-3), 3-26.

Giroux, H. (1983) Theory and Resistance in Education: a pedagogy for the opposition. Westport, CT: Bergin \& Garvey.

Giroux, H. (1985) Introduction, in P. Freire, The Politics of Education. South Hadley, MA: Bergin \& Garvey.

Giroux, H. (1988) Teachers as Intellectuals: towards a critical pedagogy of learning. Westport, CT: Bergin \& Garvey.

Giroux, H. (1991) Postmodernism, Feminism and Cultural Politics: rethinking educational boundaries. Albany, NY: SUNY Press.

Giroux, H. (1992) Border Crossings: cultural workers and the politics of education. New York: Routledge. 
Peter Mayo

Giroux, H. (1993) Living Dangerously: multiculturalism and the politics of culture. New York: Peter Lang.

Giroux, H. (1994a) Disturbing Pleasures: learning popular culture. New York: Routledge.

Giroux, H. (1994b) Doing Cultural Studies: youth and the challenge of pedagogy, Harvard Educational Review, 64(3), 247-277.

Giroux, H. (1996) Fugitive Cultures. New York: Routledge.

Giroux, H. (1997a) Pedagogy and the Politics of Hope: theory, culture and schooling. Boulder, CO: Westview Press.

Giroux, H. (1997b) Channel Surfing: race talk and the destruction of today's youth. New York: St Martin's Press.

Giroux, H. (1999) The Mouse that Roared: Disney and the end of innocence. Lanham, MD: Rowman \& Littlefield.

Giroux, H. (2000a) Impure Acts: the practical politics of cultural studies. New York: Routledge.

Giroux, H. (2000b) Stealing Innocence: corporate culture's war on children. New York: Palgrave.

Giroux, H. (2001) Public Spaces/Private Lives: beyond the culture of cynicism. Lanham, MD: Rowman \& Littlefield.

Giroux, H. (2002) Breaking into the Movies, Film and the Culture of Politics. Malden, MA: Blackwell.

Giroux, H. (2004) The Terror of Neoliberalism: authoritarianism and the eclipse of democracy. Boulder, CO: Paradigm; Aurora, Ontario: Garamond.

Giroux, H. (2005a) Against the New Authoritarianism: politics after Abu Ghraib. Winnipeg: Arbeiter Ring.

Giroux, H. (2005b) Cultural Studies in Dark Times: public pedagogy and the challenge of neoliberalism, Fast Capitalism, 1(2). http:/ / www.fastcapitalism.com (accessed 2 February 2007).

Giroux, H. (2006a) The Giroux Reader, ed. C.G. Robbins. Boulder, CO: Paradigm.

Giroux, H. (2006b) Culture, Politics and Pedagogy (J.Q. Adams, interviewer). DVD. Northampton, MA: Media Education Foundation.

Giroux, H. (2006c) Stormy Weather: Katrina and the politics of disposability. Boulder, CO: Paradigm.

Giroux, H. (2006d) Katrina and the Politics of Disposability: news reporting on the aftermath of Katrina blames the victims rather than helps them, In These Times, 14 September. http:/ / www.inthesetimes.com/site/main/article/ 2822 (accessed 2 February 2007).

Giroux, H. (2006e) Beyond the Spectacle of Terrorism: global uncertainty and the challenge of the new media. Boulder, CO: Paradigm.

Giroux, H. (2006f) America on the Edge: Henry Giroux on politics, culture, and education. Basingstoke and New York: Palgrave Macmillan.

Giroux, H (2007) The University in Chains: confronting the military-industrial-academic complex. Boulder, CO: Paradigm.

Giroux, H. (2009a) The Politics of Lying and the Culture of Deceit in Obama's America, the rule of damaged politics, Truthout, 21 September. http:/ / www.truthout.org/092109R (accessed 11 October 2009).

Giroux, H. (2009b) Brutalising Kids: painful lessons in the pedagogy of school violence, Truthout, 8 October. http:/ / www.truthout.org/10080912 (accessed 10 October 2009).

Giroux, H. (2009c) Youth in a Suspect Society: democracy or disposability? New York and London: Palgrave Macmillan. http: / / dx.doi.org/10.1057/9780230100565

Giroux, H. (2009d) Town Hall Democracy or Mass Hysteria? Rethinking the importance of the public sphere, Truthout, 26 August. http: / / www.truthout.org/082609L (accessed 12 October 2009).

Giroux, H. (2010b) Hearts of Darkness: torturing children in the War on Terrorism. Boulder, CO: Paradigm.

Giroux, H. (2010d) Higher Education, Critical Pedagogy, and the Challenge of Neoliberalism: rethinking the role of academics as public intellectuals, 18 August.

Giroux, H. (2011a) Higher Education under Attack: an interview with Henry Giroux, in The Margins of Everyday Life. http: / / marginsofeverydaylife.blogspot.com/2011/04/higher-education (accessed 30 May 2011).

Giroux, H. (2011b) On Critical Pedagogy. London: Continuum.

Giroux, H. (2012) Education and the Crisis of Public Values: challenging the assault on teachers, students, and public education. New York: Peter Lang.

Giroux, H. \& McLaren, P. (Eds) (1989) Critical Pedagogy, the State and the Struggle for Culture. Albany, NY: SUNY Press.

Giroux, H. \& Searls Giroux, S. (2004) Take Back Higher Education: race, youth and the crisis of democracy in the post-civil rights era. New York: Palgrave Macmillan. 
Giroux, H. \& Shannon, P. (1997) Cultural Studies and Education Towards a Performative Practice. New York: Routledge.

Giroux, H. \& Simon, R.I. (Eds) (1989) Popular Culture, Schooling \& Everyday Life. Westport, CT: Bergin \& Garvey.

Hall, S. (1988) The Hard Road to Renewal: Thatcherism and the crisis of the left. London: Verso.

Herrera, L. (2011) Egypt's Revolution 2.0: the Facebook factor, Jadaliyya, 12 February. http:/ / www.jadaliyya.com/pages/index/612/egypts-revolution-2.0_the-facebook-factor

Kellner, D. (2001) Reading Giroux: cultural studies, critical pedagogy, and radical democracy, in H. Giroux, Public Spaces /Private Lives: beyond the culture of cynicism. Lanham, MD: Rowman \& Littlefield.

Martin, I. (2001) Reconstructing the Agora: Towards an alternative politics of lifelong learning, Concept, 11(1), pp. 4-8.

Mayo, P. (2009a) Competitiveness, Diversification and the International Higher Education Cash Flow: the EU's higher education discourse amidst the challenges of globalisation, International Studies in Sociology of Education, 19(2), 87-103. http://dx.doi.org/10.1080/09620210903257174

Mayo, P. (2009b) Striving Against the Eclipse of Democracy: Henry Giroux' Critical Pedagogy for Social Justice, Italian Journal of Sociology of Education, 3, 254-282.

http: / / www.ijse.eu/index.php/ijse/article/viewFile/ 41 / 49 (accessed 30 May 2011).

Mayo, P. (2011) The Centrality of the State in Neoliberal Times: Gramsci and beyond, International Gramsci Journal, 3. http://www.uow.edu.au/arts/research/gramsci-journal/articles/IGJ3.pdf (accessed 29 May 2011).

Mayo, P. (2012) Politics of Indignation: imperialism, postcolonial disruptions and social change. London: Zero Books/John Hunt.

Showstack Sassoon, A. (2009) Raymond Williams, Stuart Hall, Gramsci e noi [Raymond Williams, Stuart Hall, Gramsci and Us], in G. Schirru (Ed.) Gramsci, le Culture e il Mondo [Gramsci, Cultures and the World]. Rome: Viella.

Sultana, R.G. (1985) A Theoretical Framework for a Critical Analysis of Schooling: the work of Henry A. Giroux, Education, 2(2), 1-4, 29-30.

Thompson, J. (Ed.) (2000) Stretching the Academy: the politics and practice of widening participation in higher education. Leicester: National Institute of Adult Continuing Education (NIACE).

Torres, C.A. (1998) Education, Power, and Personal Biography: dialogues with critical educators. New York: Routledge.

Williams, R. (1993) Adult Education and Social Change, in J. Mcllroy \& S. Westwood (Eds) Border Country: Raymond Williams in adult education, pp. 255-264. Leicester: National Institute of Adult Continuing Education (NIACE).

PETER MAYO is Professor in the Department of Education Studies, Faculty of Education, University of Malta. He teaches/researches in sociology of education and adult education. His authored books include Gramsci, Freire and Adult Education (Zed Books, 1999) which has subsequently been published in six other languages, Liberating Praxis (Praeger, 2004; Sense, 2009) which won an AESA Critics Choice award, Learning and Social Difference (with C. Borg, Paradigm, 2006), Learning with Adults. A Critical Pedagogical Introduction (with L. English, Sense, 2012), Politics of Indignation: imperialism, postcolonial disruptions and social change (Zero Books, 2012) and the forthcoming Echoes from Freire for a Critically Engaged Pedagogy (Continuum, 2013). Last year he won the best comparative and international research paper in Higher Education award granted by the Higher Education SIG of the Comparative International Education Society. Correspondence: peter.mayo@um.edu.mt 